\title{
EFFECT OF SEED MASS ON GERMINATION AND GROWTH IN THREE DOMINANT SPECIES IN SOUTHERN BRAZILIAN COASTAL DUNES
}

\author{
CORDAZZO, C. V. \\ Laboratório de Comunidades Vegetais Costeiras, Depto. de Oceanografia, Fundação Universidade do Rio Grande, \\ C.P. 474, CEP 96211-900, Rio Grande, RS, Brazil \\ Correspondence to: César Vieira Cordazzo, Laboratório de Comunidades Vegetais Costeiras, Depto. de \\ Oceanografia, Fundação Universidade do Rio Grande, C.P. 474, CEP 96211-900, Rio Grande, RS, Brazil, \\ e-mail: cordazzo@ecoscientia.com.br \\ Received May 14, 2001 - Accepted July 12, 2001 - Distributed August 31, 2002
}

(With 1 figure)

\begin{abstract}
The effect of seed mass on germination and growth was tested in fresh-seeds of Blutaparon portulacoides, Panicum racemosum, and Spartina ciliata, selected at random in southern Brazilian populations. The seed mass varied within a population of the three species. Both B. portulacoides and $P$. racemosum showed normal frequency distribution of seed mass, while S. ciliata did not. Significant differences were observed in seed germination between large and small seeds of all species. In all species the capacity of seedling elongation was greater in seedlings of large seeds than those of small ones. Relative growth rate of seedlings of P. racemosum and S. ciliata decreased with time in all seed mass size-classes. On the other hand, the relative growth rate of $B$. portulacoides seedlings increased during the first 40 days. Seed mass is an important biological factor, affecting seed germination, seedling elongation, and growth of these species, and favoring large seeds, specially in areas of active sand accretion like coastal dunes.
\end{abstract}

Key words: germination, seedling growth, Panicum racemosum, Spartina ciliata, Blutaparon portulacoides.

\section{RESUMO}

\section{Efeito da massa das sementes na germinação e no crescimento em três espécies} dominantes das dunas costeiras do sul do Brasil

O efeito da massa das sementes sobre a germinação e o crescimento foi testado com sementes de Blutaparon portulacoides, Panicum racemosum e Spartina ciliata coletadas aleatoriamente em populações no sul do Brasil. A massa das sementes variou dentro das populações das três espécies. Ambas, $B$. portulacoides e $P$. racemosum, mostraram distribuição normal na freqüência no peso das sementes, enquanto $S$. ciliata não apresentou distribuição normal. Diferenças significativas foram observadas na germinação das sementes entre sementes grandes e pequenas nas três espécies. A capacidade de alongamento das plântulas das três espécies é maior nas plântulas originadas de sementes grandes do que nas provenientes de sementes pequenas. As taxas de crescimento relativo das plântulas de $P$. racemosum e $S$. ciliata diminuíram com o tempo em todas as classes de massa de sementes. Por outro lado, a taxa de crescimento relativo das plântulas de B. portulacoides aumentou ao longo dos primeiros 40 dias. A massa das sementes é um importante fator biológico, porque afeta a germinação, o alongamento das plântulas e o crescimento nas espécies, favorecendo assim as sementes maiores, especialmente em áreas de ativa deposição de areias, como as dunas costeiras.

Palavras-chave: germinação, crescimento das plântulas, Panicum racemosum, Spartina ciliata, Blutaparon portulacoides. 


\section{INTRODUCTION}

Seed size (usually measured as mass) has long been regarded as an important aspect of plant reproductive biology. Traditionally, seed mass within a plant species is considered a remarkably constant characteristic (Harper et al., 1970; Silvertown, 1981). However, other studies have demonstrated that seed mass within a species or even an individual plant can vary greatly (Harper et al., 1970; Schaal, 1980). Salisbury (1942) recognized that although seed mass varied between species, seed size was correlated with habitat and tended to increase with successional maturity of the community.

Differential seed size may have several important ecological implications. Variation in seed mass within a species may affect seed germination (Schaal, 1980; Weis, 1982) and germination rate (Weis, 1982; Zhang \& Maun, 1990). Large seeds frequently have greater percent germination or emergence than small seeds (Weis, 1982; Hendrix, 1984). On the other hand, small seeds may germinate more quickly than large seeds and, thus, have a competitive advantage (Howell, 1981). Seed size also affects seedling biomass (Zimmerman \& Weis, 1983): usually, the seedlings from large seeds are larger than those from small seeds, especially in the early stages of growth (Schaal, 1980; Saverimuttu \& Westoby, 1996). The initial seedling size differences may persist until maturity (Schaal, 1980; Weis, 1982) or become imperceptible with time (Zimmerman \& Weis, 1983 ) because of the differential relative growth rate among seedlings from differently sized seeds (Lewis \& Garcia, 1979; Zhang \& Maun, 1990). Some studies (Zimmerman \& Weis, 1983) indicate that a higher relative growth rate of seedlings from small seeds exists only in the early stages of development, and/or that the RGR may be reduced in competitive conditions (Westoby et al., 1996).

The aim of this study was to (a) investigate the variation in seed size in natural populations of Panicum racemosum (Beauv.) Spreng., Spartina ciliata Brong, and Blutaparon portulacoides (St.Hil.) Mears from southern Brazilian coastal dunes; (b) determine the differences in germination and elongation of different-sized seeds of the three species; and (c) examine the effect of seed mass on seedling growth.

\section{MATERIAL AND METHODS}

\section{Seed mass variation}

Seed size obviously refers directly to seed volume. However, because seed shapes are so varied, volume is often difficult to measure, and mass is commonly used as a size index (Wilson, 1983).

The mass of 590, 580, and 665 freshseeds of Panicum racemosum, Spartina ciliata and Blutaparon portulacoides respectively, selected at random in southern Brazilian populations $\left(32^{\circ} 27^{\prime} \mathrm{S} ; 52^{\circ} 21^{\prime} \mathrm{W}\right)$ were recorded with an electronic balance. The cumulative means of seed mass in the samples were calculated as increased. When the sample size exceeded 300, 450, and 525 seeds of Panicum, Spartina, and Blutaparon, respectively, the mean seed mass and the variance remained fairly constant, and it was thus assumed that the samples reflected the true variation in the seed population for all three species. The distributions of individual seed masses for each species were tested for normality (Kolmogorov-Smirnov test; Zar, 1984).

\section{Effect of seed mass on germination}

One hundred seeds from each size class (large, medium, and small) of each species were weighed and individual seeds kept separately in four replicate plastic boxes, each with 25 compartments $(1 \times 1 \mathrm{~cm})$. It was therefore possible to correlate their size with time and total germination. The three size classes were chosen to avoid overlapping of in their seed masses.

The twenty-five seeds per box were soaked in $2 \mathrm{ml}$ of distilled water per compartment of each plastic box, on two layers of filter paper (Whatman N. 1). The plastic boxes were placed randomly in an incubator maintained at alternating temperatures with 12 hours of ilumination at $30^{\circ} \mathrm{C}$ and 12 hours of darkness at $15^{\circ} \mathrm{C}$. Previous studies showed that these germination conditions were the best for the three species (Cordazzo, 1994). Germinated seeds were counted every day and removed. At the end of the experiment, all ungerminated seeds were examined for viability with the tetrazolium test. Germination percentage and germination rate (GR) in each size class were recorded and transformed to arcsin square root values before analysis of data using a ONE-WAY analysis of variance (ANOVA). 
Tukey's multiple range test was used when the ANOVA showed a significant difference (Zar, 1984). However, the data shown in the tables have not been transformed. The germination rate was calculated according to Mugnisjah \& Nakamura (1986) and can be expressed as follows:

$$
\mathrm{GR}=100 / \sum \mathrm{Ni} \times \sum(\mathrm{Ni} / \mathrm{Ti})
$$

where Ti is the day after germination beginning and $\mathrm{Ni}$, the number of seeds germinating on day Ti. We also observed, a time lag (time in days between the beginning of the experiment and that of germination). Together, lag time, germination rate, and final germination proportion are considered an adequate indication of germination performance for most species (Shipley \& Parent, 1991).

\section{Effect of seed mass on seedling growth}

One-hundred 5-day old seedlings were selected from each size class of seed mass and eighty were planted individually in $9 \mathrm{~cm}$ plastic pots filled with 4:1 sand and John Innes compost N. 2 mixture. The pots were then placed randomly on a bench in an environmental cabinet kept at $25^{\circ} \mathrm{C}$ day (14 hours) and $15^{\circ} \mathrm{C}$ (10 hours) night temperatures. Each 10 days after planting, twenty plants from each size class were harvested and gently washed. The dry masses of leaves and roots were measured after 48 hours in an oven at $80^{\circ} \mathrm{C}$. There were four successive harvests. Twenty 5day old seedlings from each size class were dried, measured, and used as the initial seedling biomass of each size class. Measurements were transformed to natural logarithms for normalization prior to variance analysis. Relative growth rate (RGR) was then calculated according to the equation;

$$
\mathrm{RGR}=(\ln \mathrm{W} 2-\ln \mathrm{W} 1) / \mathrm{t} 2-\mathrm{t} 1
$$

where $\mathrm{t}$ is the time in days and $\mathrm{W} 1$ and $\mathrm{W} 2$ are the dry masses per plant in milligrams at $\mathrm{t} 1$ and t2, respectively (Hunt, 1990).

\section{RESULTS}

\section{Seed mass variation}

The seed mass of Panicum racemosum varied within the population by a factor of about four, from 3.2 to $12.4 \mathrm{mg}$ per seed. The mean seed mass of this population was $7.9 \pm 0.08 \mathrm{mg}$ (mean \pm standart error), which was lower than the mode $(8.9 \mathrm{mg})$. The frequency distribution of seed mass was normal (D-statistic 0.0602).

Seed mass of Spartina ciliata varied greatly, from 0.1 to $5.6 \mathrm{mg}$, with a mean of $2.4 \pm 0.03 \mathrm{mg}$. which was equal to the mode. The seed mass distribution was non-normal (D-statistic 0.0535), skewed to the right $(\mathrm{g} 1=0.085)$, and platykurtic $(\mathrm{g} 2=-0.295)$.

The mean mass of the field population of Blutaparon portulacoides seeds was $0.9 \pm 0.01 \mathrm{mg}$ and seed mass ranged from 0.1 to $1.8 \mathrm{mg}$ with a modal class of $0.8 \mathrm{mg}$, lower than the mean. The seed mass distribution was normal (D-statistic 0.0582).

\section{Effect of seed mass on germination}

The total germination percentage of Panicum racemosum for small seeds (less than $6.8 \mathrm{mg}$ ) was $16 \%$, and increased significantly to $30.4 \%$ and $31.2 \%$ for medium and large seeds, respectively (Table 1). The germination rate of seeds in the three classes showed a significant difference only in relation to small versus medium and large seeds (Table 1). Similarly, the lag time was different from medium and large seeds (4 days) to that of the small ones (7 days) (Table 1).

The total germination was significantly different (large $>$ medium $>$ small) among the different seed-size classes in Spartina ciliata (Table 1). However, the rate of seed germination in different sizes was not significantly different (Table $1)$. The lag time for large and medium seeds was 2 days and 4 days for small ones (Table 1).

The percentage of Blutaparon portulacoides seeds germinating at various times are shown in Table 1. Analysis of the data showed significant differences in total germination of large and medium seeds in relation to small seeds. The rate of germination showed similar differences. The lag time of large seeds (1 day) was different for medium and small seeds (2 days) (Table 1$)$.

\section{Seed mass effect on seedling growth}

The effect of seed mass on seedling growth of Panicum racemosum during the 40 days after germination are represented in Fig. 1A. Large seeds produced heavier seedlings than the smaller ones did. However, the differences in seedling mass were significant only between 20 and 30 days. Thereafter, the differences disappeared completely. 

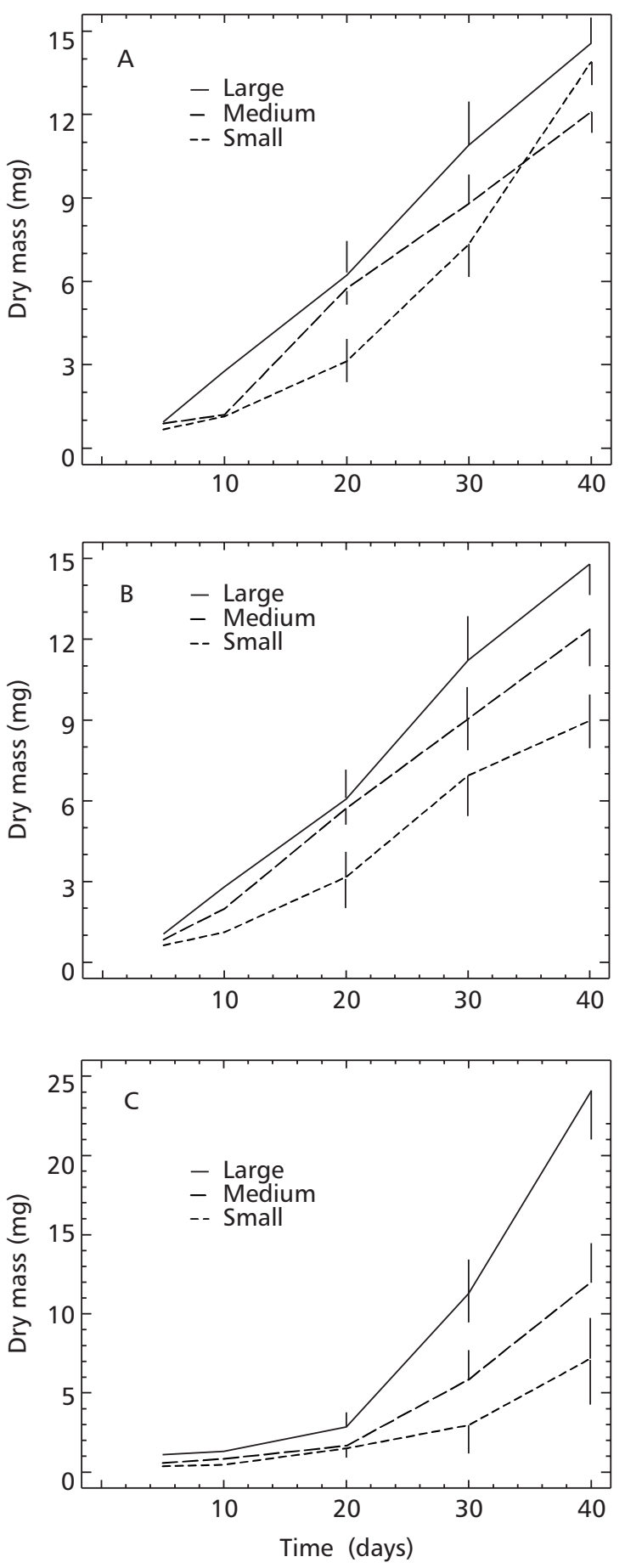

Fig. 1 - Seedling growth (mean \pm SE) expressed as dry mass $(\mathrm{mg})$ over 40 days from three different seed-size classes (seed mass) in (A) Panicum racemosum, (B) Spartina ciliata, and (C) Blutaparon portulacoides. 
TABLE 1

Lag time (L), mean $\pm \mathrm{SE}$ of germination $(\mathrm{G} \%)$ and rate of germination (RG) of $P$. racemosum, S. ciliata, and $B$. portulacoides in three different-sized classes of seeds (expressed as seed mass) from a population of southern Brazilian coastal dunes.

\begin{tabular}{|c|c|c|c|}
\hline Size (mg) & L (days) & G\% & RG \\
\hline \multicolumn{4}{|l|}{ Panicum racemosum } \\
\hline Large $\quad(10.3 \pm 0.6)$ & 4 & $31.2 \pm 0.7$ & $22.1 \pm 0.7$ \\
\hline Medium $\quad(8.4 \pm 0.6)$ & 4 & $30.4 \pm 0.8$ & $21.5 \pm 1.2$ \\
\hline Small $\quad(5.7 \pm 0.7)$ & 7 & $16.6 \pm 0.8 \quad$ (b) & $11.1 \pm 1.3$ \\
\hline \multicolumn{4}{|l|}{ Spartina ciliata } \\
\hline Large $\quad(3.5 \pm 0.18)$ & 2 & $98.0 \pm 0.2 \quad$ (a) & $16.9 \pm 0.5$ \\
\hline Medium $(2.5 \pm 0.11)$ & 2 & $88.2 \pm 1.3 \quad$ (b) & $16.8 \pm 0.4$ \\
\hline Small $\quad(1.3 \pm 0.03)$ & 4 & $75.1 \pm 1.7$ & $17.0 \pm 0.7$ \\
\hline \multicolumn{4}{|l|}{ Blutaparon portulacoides } \\
\hline Large $\quad(1.2 \pm 0.01)$ & 1 & $72.0 \pm 0.4 \quad$ (a) & $33.5 \pm 3.3$ \\
\hline Medium $\quad(0.7 \pm 0.02)$ & 2 & $65.2 \pm 2.5 \quad$ (a) & $33.7 \pm 2.4$ \\
\hline Small $\quad(0.3 \pm 0.01)$ & 2 & $32.0 \pm 1.6 \quad(b)$ & $25.8 \pm 0.6 \quad(b)$ \\
\hline
\end{tabular}

Different letters in the same column indicate significant differences according to Tukey's multiple range test at 5\% significance level.

The relative growth rate (RGR) decreased significantly over the 40 days after germination in seedlings from large seeds (Table 2). In seedlings from medium and small seeds, the relative growth rate increased significantly between 10 and 20 days (Table 2), but decreased significantly in seedlings from medium-sized seeds after 30 days (Table 2), while in seedlings from small seeds it was similar to the initial value. Significant differences were observed between seedlings from large and small seeds of Spartina ciliata harvested at 20, 30, and 40 days. The seedlings from medium-sized seed did not differ from the extremes (Fig. 1B). Similarly to $P$. racemosum, the relative growth rate of seedlings of Spartina ciliata from large seeds decreased significantly with time (Table 2). The seedlings from medium-sized and small seeds, however, increased in relative growth rate (RGR) at 20 days, but decreased again significantly after 30 days (Table 2 ). The dry mass for the three seed- size classes of Blutaparon portulacoides is represented in Fig. 1C. There were large differences in the dry matter accumulated in seedlings developed from large and small seed-size classes. After 40 days, the seedlings developed from the former were two to three times larger than those developed from medium and small seeds, respectively. The relative growth rate (RGR) increased with age increase of seedlings from large and medium seeds (Table 2) while remaining constant after 20 days in seedlings from small seeds (Table 2).

\section{DISCUSSION}

Seed size is one of the more stable morphological characteristics in many plant species (Harper et al., 1970; Silvertown, 1981). However, various studies have demonstrated that seed size within a species or even an individual plant can vary greatly (Schaal, 1980; Hendrix, 1984). 
TABLE 2

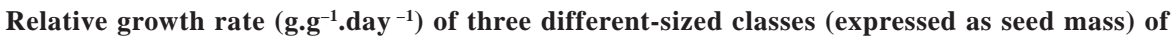
$P$. racemosum, $S$. ciliata, and $B$. portulacoides over 40 days after germination.

\begin{tabular}{|c|c|c|c|c|}
\hline & \multicolumn{4}{|c|}{ Time (days) } \\
\hline & 0-10 & $10-20$ & $20-30$ & $30-40$ \\
\hline \multicolumn{5}{|l|}{ Panicum } \\
\hline Large & 0.103 (a) & 0.08 (b) & $0.06(\mathrm{c})$ & $0.03(\mathrm{~d})$ \\
\hline Medium & 0.085 (a) & 0.10 (b) & $0.04(\mathrm{c})$ & $0.03(\mathrm{c})$ \\
\hline Small & 0.052 (a) & $0.09(b)$ & 0.09 (b) & $0.06(\mathrm{c})$ \\
\hline \multicolumn{5}{|l|}{ Spartina } \\
\hline Large & 0.098 (a) & $0.08(\mathrm{a})$ & $0.05(\mathrm{~b})$ & $0.02(\mathrm{c})$ \\
\hline Medium & 0.087 (a) & $0.10(a)$ & $0.04(b)$ & $0.03(b)$ \\
\hline Small & $0.055(\mathrm{a})$ & $0.10(b)$ & $0.08(a b)$ & $0.02(\mathrm{c})$ \\
\hline \multicolumn{5}{|c|}{ Blutaparon } \\
\hline Large & 0.016 (a) & $0.05(b)$ & $0.09(\mathrm{c})$ & 0.11 (c) \\
\hline Medium & 0.015 (a) & 0.04 (a) & $0.08(b)$ & 0.09 (b) \\
\hline Small & 0.005 (a) & 0.07 (b) & 0.04 (b) & $0.06(b)$ \\
\hline
\end{tabular}

Different letters in the same row represent means statistically different according to Tukey's multiple range test at 5\% significance level.

Several factors such as (a) competition between individual seeds for limited resources (Stanton, 1984), (b) microhabitat differences microhabitat (Keddy, 1982), (c) genetic control (Stanton, 1984), (d) plastic responses to environmental variation (Winn, 1988), and (e) trade-offs between seed size and seed number (e.g., Panicum racemosum, Cordazzo \& Davy, 1994) may be responsible for this variation. Baker (1972) found a correlation between seed mass of individual seeds of nearly 2500 taxa over a range of environment conditions. He estimated a value of environmental $6.48 \mathrm{mg}$ as mean seed mass for coastal strand and dunes, a value lower than the mean seed mass obtained from Panicum racemosum, but higher than that from Spartina ciliata and Blutaparon portulacoides.

Seed-size variation of a species may have ecological significance in a number of ways. The characteristic seed mass of a plant species probably represents a compromise between the requirements for dispersal and for establishment (Harper, 1977; Swanborough \& Westoby, 1996). The need for wide dispersal would favor small-seed evolution (Fenner, 1983); the need for successful establishment creates a selection pressure for large seeds (Jurado \& Westoby, 1992; Lloret et al., 1999; Kidson \& Westoby, 2000).

The germination experiments indicated that small seeds of $P$. racemosum, $S$. ciliata, and $B$. portulacoides have lower percent germination than larger seeds, suggesting a positive effect of seed mass on germination, which results from other species supports (Schaal, 1980; Zhang \& Maun, 1990; Shaukat et al., 1999; Kidson \& Westoby, 2000). This behavior probably is an adaptation to establishment in areas with active sand burial, where the greater food reserves of large seeds may be an advantage. 
The large-seed germination rate was significantly higher than that of small seeds, except for Spartina ciliata, which presented no differences in the three size classes. Results showing that large seeds of Panicum racemosum and Blutaparon portulacoides have higher germination rates than small ones do are in agreement with results on other species such as Lupinus texensis (Schaal, 1980), Impatiens capensis (Howell, 1981), Mirabilis hirsuta (Weis, 1982), Xanthium strumarium (Zimmerman \& Weis, 1983), Agropyron psammophilum (Zhang \& Maun, 1990), Panicum virgatum (Zhang \& Maun, 1991), Erica vagans (Vera, 1997), and Acacia nilotica (Shaukat et al., 1999). Some studies by Stanton (1984), Zhang \& Maun (1990), and Seiwa (2000) have suggested that early germinating seedlings have a higher competitive ability than later ones because they occupy the available space and preempt the limited resources. On the other hand, later-germinating seedlings can suffer increased mortality and/or reduced growth (Zimmerman \& Weis, 1983). In the southern Brazilian sand-dune environment, the supply of nutrients is limited (Costa et al., 1991) and early germinating seedling probably have a better chance of growth and establishment at locations where seedling density is high, like depressions between dune ridges. The three species studied also showed that seedlings from large seeds present significantly higher elongation in darkness than do those from small seeds (Cordazzo, 1994). A small seed implies a small embryo with few food reserves. The seedling from a small seed is dependent from a very early phase in growth on its own independent assimilation. In contrast, the seedling from a large seed may have sufficient reserves to continue growth for a much longer period (Harper, 1977; Saverimuttu \& Westoby, 1996). A high capacity for elongation of seedlings from large seeds would favor seedlings in areas of active sand accretion, as has been observed for other species (Howell, 1991; Maun, 1997).

It is generally agreed that large seeds tend to produce larger seedlings (Schaal, 1980; Weis, 1982; Zhang \& Maun, 1990). Two patterns of absolute growth rate of the subsequent seedlings have shown that: (i) consistently greater absolute growth of seedlings from large seeds than from small seeds is maintained until maturity (Schaal, 1980; Stanton, 1984) and (ii) the initial size advantage of seedlings from large seeds may disappear with time because of higher relative growth rate of seedlings from small seeds (Lewis $\&$ Garcia, 1979). The results with seedlings of Panicum racemosum showed that the effect of seed mass was very important only for germination characters, but did not affect seedling dry mass after 40 days. However, seedlings from large seeds were significantly larger than those from small seeds at 20 and 30 days old. Some studies (Howell, 1981; Zimmerman \& Weis, 1983) suggest that seedlings from small seeds have a higher relative growth rate (RGR) than those from large seeds. Thus, the initial size advantage of large seeds compared with small ones may be short-lived, e.g., seedlings of $P$. racemosum. Seedlings from large seeds showed a continual decrease in relative growth rate with time, although seedlings from small ones presented an increase in relative growth rate until they were 30-days old. Zhang \& Maun (1990) found similar RGR values for Agropyron psammophilum but, in contrast, the decrease in relative growth rate of seedings from small seeds was greater than that of those from large ones.

There were significant advantages, maintained throughout, in dry matter accumulated in seedlings developed from large seeds of Spartina ciliata and Blutaparon portulacoides in relation to those developed from small ones. However, the relative growth rate (RGR) of seedlings from all seed-size classes fluctuated with time. For example, the RGR in Spartina ciliata seedlings decreased significantly from young plants to 40-day old ones in large seeds, but this reduction occurred at 30 days for seedlings from medium seeds and was different only at 20 days for seedlings from small seeds. Meanwhile, the seedlings of Blutaparon portulacoides, a pioneer species in the southern Brazilian coastal dunes, showed a relative growthrate with time. However, the differences were significant only in seedlings from large-and-medium seeds. Grime (1979) has suggested that high RGR may be adaptive for colonizing species as it allows them to monopolize available space rapidly.

We conclude that the selective importance of fruit size in Panicum racemosum is potentially important only for germination of seeds and early growth of seedlings; seed mass effects on seedling growth disappear rapidly, at least under glasshouse conditions. On the other hand, the effects of seed mass were very important for the germination and growth of seedlings of Spartina ciliata and Blutaparon portulacoides, and could be of adaptive 
significance in establishing and maintaining the populations, because seedlings from large seeds are able to survive hazards (Westoby et al., 1996; Bonfil, 1998; Khurana \& Singh, 2000) including coastal dunes stresses such as sand burial, drought, and few mineral nutrients. However, further studies are required to determine if this behavior and these characteristics are maintained in the field under conditions of intra- and inter-species competition.

Acknowledgments — The author thanks the Brazilian National Research Council (CNPq) for financial support (Proc. \# 420040/00-5).

\section{REFERENCES}

BAKER, H. G., 1972, Seed weight in relation to environmental conditions in California. Ecology, 53: 997-1010.

BONFIL, C., 1998, The effects of seed size, cotyledon reserves, and herbory on seedling survival and growth in Quercus rugosa and Q. lausina (Fabaceae). Am. J. Bot., 85(1): 79-87.

CORDAZZO, C. V., 1994, Comparative population studies of four dominant plants of southern Brazilian costal dunes. Ph.D. Thesis, University of East Anglia, Norwich, UK.

CORDAZZO, C. V. \& DAVY, A. J., 1994, Seed production and seed quality of the dune building grass Panicum racemosum Spreng. Acta Bot. Bras., 8(2): 193-203.

COSTA, C. S. B., SEELIGER, U. \& CORDAZZO, C. V., 1991, Leaf demography and decline of Panicum racemosum populations in coastal foredunes of southern Brazil. Can. J. Bot., 69: 1593-1599.

FENNER, M., 1983, Relationships between seed weight, ash content and seedling growth in twenty-four species of Compositae. New Phytol., 95: 697-706.

GRIME, J. P., 1979, Plant strategies and vegetation processes. John Wiley amd Sons, Chichester.

HARPER, J. L., LOVELL, P. H. \& MOORE, K. G., 1970 , The shapes and sizes of seeds. Ann. Rev. Ecol. Syst., 1: 327-356.

HARPER, J. L., 1977, Population biology of plants. Academic Press, London.

HENDRIX, S. D., 1984, Variation in seed weight and its effects on germination in Pastinaca sativa $\mathrm{L}$. (Umbelliferae). Am. J. Bot., 71: 795-802.

HOWELL, N., 1981, The effect os seed size and relative emergence time on fitness in a natural population of Impatiens capensis Meerb. (Balsaminaceae). Am. Midl. Naturalist, 105: 312-320.

HUNT, R., 1990, Basic growth analysis. Unwin Hyman Ltd., London.
JURADO, E. \& WESTOBY, M., 1992, Seedling growth in relation to seed size among species of arid Australia. $J$. Ecol., 80: 407-416.

KEDDY, P. A., 1982, Population ecology on an environmental gradient: Cakile edentula on a sand dune. Oecologia, 52: 348-355.

KHURANA, E. \& SINGH, J. S., 2000, Influence of seed size on seedling growth of Albizia procera under different soil water levels. Ann. Bot., 86(6): 1185-1192.

KIDSON, R. \& WESTOBY, M., 2000, Seed mass and seedling dimensions in relation to seedling establishment. Oecologia, 125(1): 11-17.

LEWIS, E. J. \& GARCIA, J. A., 1979, The effect of seed weight and coleoptile tiller development on seedling vigour in tall fescue, Festuca arundinacea Screb. Euph., 28: 393-402.

LLORET, F., CASANOVAS, C. \& PENUELAS, J., 1999, Seedling survival of Mediterranean shrubland species in relation to root:shoot ratio, seed size and water and nitrogen use. F. Ecol., 13(2): 210-216.

MAUN, M. A., 1997, Adaptations of plants to burial in coastal sand dunes. Can. J. Bot., 76: 713-738.

MUGNISJAH, W. Q. \& NAKAMURA, S., 1986, Methanol and etanol stress for seed vigor evaluation in soybean. Seed Sci. Technol., 14: 95-103.

SALISBURY, E. J., 1942, The reprodutive capacity of plants. Bell and Sons, London.

SAVERIMUTTU, T. \& WESTOBY, M., 1996, Seedling longevity under deep shade in relation to seed size. $J$. Ecol., 84: 681-689.

SCHAAL, B. A., 1980, Reproductive capacity and seed size in Lupinus texensis. Am. J. Bot., 67: 703-709.

SEIWA, K., 2000, Effects of seed size and emergence time on tree seedling establishment: Importance of developmental contraints. Oecologia, 123(2): 208-215.

SHAUKAT, S. S., SIDDIQUI, Z. \& AZIZ, S., 1999, Seed size variation and its efects on germination, growth and seedling survival in Acacia nilotica subsp. Indica (Benth.) Brenan. Pak. J. Bot., 31(2): 253-263.

SHIPLEY, B. \& PARENT, M., 1991, Germination responses of 64 wetland species in relation to seed size, minimum time to reproduction and seedling relative growth rate. Functional Ecology, 5: 111-118.

SILVERTOWN, J., 1981, Seed size, life span, and germination date as coadapted features of plant life history. Am. Naturalist, 118: 860-864.

STANTON, M. L., 1984, Development and genetic sources of seed weight variation in Raphanus raphanistrum $\mathrm{L}$. (Brassicaceae). Am. J. Bot., 71: 1090-1098.

SWANBOROUGH, P. \& WESTOBY, M., 1996, Seedling relative growth rate and its components in relation to seed size: phylogenetically independent contrasts. F. Ecol., 10: 176-184. 
VERA, M. L., 1997, Effects of altitude and seed size on germination and seedling survival of heathland plants in north Spain. Plant Ecol., 133(1): 101-106.

WEIS, M. I., 1982, The effects of propagule size on germination and seedling growth in Mirabilis hirsuta. Can. J. Bot., 60: 1868-1874.

WESTOBY, M., LEISHMAN, M. \& LORD, J., 1996, Comparative ecology of seed size and dispersal. Phil. Trans. Royal Soc., 351(1345): 1309-1318.

WILSON, M. F., 1983, Plant reprodutive ecology. John Wiley \& Sons, New York.

WINN, A. A., 1988, Ecological and evolutionary consequences of seed size in Prunella vulgaris. Ecology, 69: 15371544.
ZAR, J. H., 1984, Biostatistical analysis. Prentice-Hall Inc., Englewood Clifffs, New Jersey.

ZHANG, J. \& MAUN, M. A., 1990, Seed size variation and its effects on seedling growth in Agropyron psammophilum. Bot. Gaz., 151: 106-113.

ZHANG, J. \& MAUN, M. A., 1991, Establishment and growth of Panicum virgatum L. seedlings on Lake Erie sand dunes. Bull. Torrey Bot. Club, 118: 141-153.

ZIMMERMAN, J. K. \& WEIS, M. I., 1983, Fruit size variation and its effects on germination and seedling growth in Xanthium strumarium. Can. J. Bot., 61: 23092315. 